\title{
MEMBACA POLITIK ISLAM PASCA REFORMASI
}

\author{
Hermanu Joebagio ${ }^{1}$
}

\begin{abstract}
Abstrak
Krisis multidimensi 1997-1998 yang ditandai dengan kenaikan mata uang dollar antara Rp.10.000 hingga Rp.15.000/dollar berakibat hancurnya fundamental ekonomi Indonesia. Kondisi ini menjadi triggered Muslim Islam untuk membangun orientasi-orientasi Islam politik.Islam politik dan politik Islam berbeda dalam pemaknaannya. Islam politik merupakan perjuangan kelompok Muslim garis keras untuk mendapatkan dimensi kekuasaan, dan ketika dimensi kekuasaan telah teraih, al-Qur'an, al-Hadits, dan Fiqh sebagai philosophische grondslag. Sementara itu politik Islam merupakan perjuangan meraih kekuasaan politik dengan menggunakan simbol Islam sebagai basis recruitmentmassa.Ketika kekuasaan dapat diraih, mereka menggunakan Pancasila sebagai philosophische grondslag. Karena itu perkembangan Islam politik pada awal reformasi sangatlah kuat, tetapi selama lima belas tahun pasca reformasi justru orientasi Islam politik menjadi sangat radikal, dan orientasi politik mereka mengikuti pola politik yang bersifat "teror".

Melihat kondisi partai politik Islam pasca reformasi yang begitu lebar variannya, dan ada kecenderungan elit politik partai politik Islam belum 100 persen menjadikan Pancasila sebagai philosophische grondslag dapat memicu rendahnya partisipasi pemilih. Partai politik Islam yang banyak variannya itu ada gagasan untuk menyederhanakan. Keberhasilan Soeharto menyederhanakan partai politik dalam tiga mainstream sosial-demokrat (Golkar), nasionalis (PDI), dan Islam (PPP) sangat baik. Bila tiga mainstream itu dihidupkan kembali dalam bentuk baru, dan diletakkan pada fase lima belas tahun reformasi, maka partisipasi pemilih terhadap partai politik Islam berbanding lurus dengan kekuatan pemilih mayoritas.
\end{abstract}

\section{Kata kunci: Politik, Islam, Reformasi}

\section{Pendahuluan}

Perjalanan sejarah bangsa Indonesia pada setiap perubahan politik memacu timbulnya kegaduhan, dan menelan korban manusia. Perubahan dari orde lama menuju orde baru, maupun orde reformasi selalu menelan korban. Pada era menuju reformasi ditandai dengan penembakan terhadap mahasiswa demonstran dan pembakaran mall, gudang rokok milik Gudang Garam, toko kelontong, dan rumah menjadi sasaran target. Di Jakarta, Solo, dan kota lain, desain kerusuhan poltik itu sangat sempurna. Apabila membandingkan dengan peperangan semesta pada masa kolonialisme disebut 'bumi hangus' untuk menunjukkan masih adanya eksistensi kekuasaan politik.

Persoalan politik dan ekonomi sangat kental dalam setiap perubahan politik, di samping persoalan kepemimpinan politik yang sudah tidak selaras lagi dengan idealisasi rakyat Indonesia. Orde baru di bawah kepemimpinan Soeharto menganut sistem, disebut patrimonialism-authoritarianism associated with industrialization and

\footnotetext{
${ }^{1}$ Hermanu Joebagio, Guru Besar Sejarah Politik Islam UNS Surakaarta. Tulisan ini pernah disampaikan dalam "Stadium General pada Civitas Academika Program Studi Pendidikan Sejarah FPIPS IKIP PGRI Madiun, Selasa 13 Oktober 2015.
} 
modernisation. ${ }^{2}$ Sistem ini ditujukan untuk melindungi proses pembangunan ekonomi, dan pembangunan itu dirancang dan dikuasai oleh tripartite, yang meliputi bureaucratic-polity, military, Chinese businessmen. $^{3} \quad$ Tripartite merupakan fiefdoms $^{4}$ ekonomi yang menimbulkan kemandulan partisipasi ekonomi dan politik, sekaligus memicu perpecahan komponen kelompok politik, khususnya terhadap masyarakat Islam. Perpecahan politik akibat kuatnya state-centered. ${ }^{5}$ Sisi lain yang lebih penting adalah implikasi dari sistem ekonomi yang dikuasai tripartite adalah tidak terbentuk kelas menengah (the leisure class) yang kokoh yang mendukung perekonomian nasional. Kendali tripartite itu, berakibat sulit bagi pelaku ekonomi menengah-bawah untuk mendapatkan pembagian kue nasional yang memadai.

Desain pembangunan ekonomi di atas, dan desain budaya politik orde baru yang mengutamakan keseragaman, justru menghancurkan nilai-nilai keberagaman. Dalam pemikiran Robert A. Dahl, ketika nilai-nilai keberagaman dihancurkan oleh desain pembangunan ekonomi, dan budaya politik, dapat dipastikan tidak bakal tumbuh kehidupan demokrasi. ${ }^{6}$ Karena demokrasi itu dapat tumbuh bila struktur kehidupan masyarakat dalam posisi modern, dynamic, dan pluralist (MDP). ${ }^{7}$
Fenomena pembangunan politik dan ekonomi sangat disadari oleh the founding father bangsa Indonesia. Karena itu desain pembangunan politik pertama kali adalah unity in diversity (bhinneka tunggal ika). Mengapa demikian? Mereka sadar bahwa unity in diversity adalah jalan menuju posisi MDP. Relasi-relasi etnisitas dan religiusitas untuk yang pertama kali harus dibangun, sebagai landasan menuju tumbuhnya demokrasi.

Nilai-nilai yang terkandung dalam unity in diversity adalah: (1) pengakuan terhadap nilai-nilai keberagaman kehidupan, baik etnisitas maupun religiusitas; (2) jiwa kegotongroyongan dan solidaritas organik yang melekat pada unity in diversity itu akan bermutasi menjadi kekuatan bangunan relasi kesepadanan sosial politik; (3) pengakuan terhadap nilai-nilai keberagaman dan tumbuhnya relasi kesepadanan politik, secara konstruktivistis akan membentuk persepsi rasional manusia Indonesia terhadap ideologi Pancasila. ${ }^{8}$

Ketika ruang politik dan ekonomi dikendalikan tripartite, serta dialog ruang publik direpresi, maka arus perlawanan politik terhadap pemerintah telah dimulai. Untuk itu pemerintah menerapkan strategi beamtenstaat. Strategi itu didefinisikan sebagai the state as bureaucratie machine. ${ }^{9}$ Melalui beamtenstaat itu, pemerintah

2 Harold Croach, The Regulation of Military Bureaucratic Regimes: the Indonesian Case (Canberra: ANU Departement of Political and Social Change Research School of Pasific Studies, 1986), hlm. 2-19.

${ }^{3}$ Ibid., hlm. 9-10.

${ }^{4}$ Konsep fiefdoms adalah konsep politik bersifat arkhais (kuno) yang dianut oleh kerajaan tradisional. Kerajaan itu mempraktikan fiefdoms berbentuk pemberian tanah apanage (lungguh). Tanah diberikan raja kepada para pangeran untuk menghidupi keluarga mereka. Dan, para pangeran menyewakan kepada petani melalui bagi-hasil. Zaman orde baru fiefdoms merupakan sistem pengaplingan ekonomi yang mendorong tindakan monopolistik, yang tidak memberi ruang kepada khalayak masyarakat berpartisipasi dalam kegiatan ekonomi. Masyarakat khalayak hanya dapat melakukan kegiatan ekonomi yang sifatnya periferal, misalnya pengrajin rumahan berskala kecil. Aktivitas ekonomi dari hulu hingga hilir sudah dikuasai oleh para kartel-kartel tripartite.

${ }^{5}$ Bahtiar Effendy, Masyarakat Agama dan Pluralisme Keagamaan (Yogyakarta: Galang Press, 2001), hlm. 18-20.

${ }_{6}^{6}$ Robert A. Dahl, Demokrasi dan Para Pengkritiknya (Jakarta: Yayasan Obor Indonesia, 1992), hlm. 1-35.

7 lbid.

${ }^{8}$ Robert Cribb, "The Historical Roots of Indinesia's New Order: Beyond the Colonial Comparason", in Edward Aspinall \& Greg Fealy, Soeharto's New Order and its Legacy, hlm. 67-79; lihat pula Susanto Zuhdi, Nasionalisme, Laut dan Sejarah (Jakarta: Komunitas Bambu, 2014), hlm. 13. 
menempatkan aparat intelejen untuk matamatai warganegara. Dengan landasan itu, orde baru secara sempurna menerapkan strategi politik Snouck Hurgronje terhadap Muslim. Muslim dipandang sebagai kelompok kiri yang berjuang melawan represi politik, serta memperjuangkan persamaan hak dan kewajiban bagi seluruh rakyat Indonesia, baik dalam perspektif politik, ekonomi, dan budaya. ${ }^{10}$

\section{Islam Politik atau Politik Islam}

Krisis multidimensi 1997-1998 yang ditandai dengan kenaikan mata uang dollar antara Rp.10.000 hingga Rp.15.000/dollar berakibat hancurnya fundamental ekonomi Indonesia. Kondisi itu menjadi triggered Muslim Islam untuk membangun orientasiorientasi Islam politik. Islam politik dan politik Islam berbeda dalam pemaknaannya. Islam politik merupakan perjuangan kelompok Muslim garis keras untuk mendapatkan dimensi kekuasaan, dan ketika dimensi kekuasaan telah diraih, maka, al-Qur'an, al-Hadits, dan Fiqh sebagai philosophische grondslag. Sebaliknya dalam politik Islam, perjuangan untuk meraih kekuasaan politik menggunakan simbolsimbol Islam sebagai basis recruitment massa. Ketika kekuasaan sudah diraih, mereka menggunakan Pancasila sebagai philosophische grondslag.

Perkembangan Islam politik pada awal reformasi cukuplah kuat, bahkan terbersit keinginan membangun Negara Islam / Negara Kekhalifahan, tetapi selama lima belas tahun pasca reformasi justru orientasi-orientasi Islam politik menjadi radikal. Bahkan orientasi Islam politik mengikuti pola-pola politik yang bersifat "terror". Model orientasi politik tersebut justru berseberangan dengan gagasan reformasi yang salah satunya menjunjung tinggi demokrasi. Model orientasi politik "terror" justru kekuatan politik mereka menjadi mandul ketika berhadapan dengan nilai-nilai keberagaman, solidaritas organik, dan ideology Pancasila yang sudah lama melekat dalam kehidupan bangsa Indonesia.

Orientasi-orientasi Islam politik menjadikan kelompok politik itu sangat eksklusif terhadap agama dan orientasi politik lainnya. Mereka menuntut nilai-nilai dasar Islam dalam al-Qur'an, al-Hadits, dan Fiqh sebagai philosophische grondslag. Pada sisi lain, warisan historis menunjukkan masyarakat bangsa Indonesia adalah multietnisitas dan multi-religiusitas, sehingga banyak masyarakat bangsa menolak tindakan radikal dan anarkhis. ${ }^{11}$ Masyarakat bangsa, terutama berada di pedesaan menyukai tipologi gotong royong dan solidaritas/kesetiakawanan. Tipologi Islam politik ingin membangun teokrasi dengan pendekatan dunya-akhirat, dengan al-Quran, al-Hadits, dan Fiqh sebagai philosophische grondslag.

${ }_{9}^{9}$ Strategi politik beamtenstaat muncul ketika orgnisasi politik di Hindia Belanda semakin radikal. Sarekat Islam menjadi sangat radikal ketika terkontaminasi pemikiran revolusioner, dan pada sisi lain Perhimpunan Indonesia dan Indische Partij sudah mencanangkan merdeka dalam kiprah pergerakannya yang termaktub dalam anggaran dasar dan anggaran rumah tangga partai tersebut. Gerakan kepartaian di Hindia Belanda semakin massif pada akhir Perang Dunia I, sebagai akibat Presiden Amerika Serikat, yakni Woodrow Wilson mencanangkan prinsip hak menentukan nasib sendiri terhadap negara-negara yang diinvasi oleh Jerman, Italia, dan Turki. Dalam situasi dilematis justru pemerintah Belanda menerapkan strategi politik beamtenstaat. Lihat Ruth McVey, "The Beamtenstaat in Indonesia", in Benedict Anderson \& Audrey Kahin, Interpreting Indonesian Politics: Thirteen Contributions to the Debate, Interim Reports Series No. 62. Ithaca, New York: Cornell Modern Indonesia Project Cornell University, 1982, hlm. 84-91.

10 Kazuo Shimogaki, Kiri Islam: Antara Modernisme dan Post Modernisme, Telaah Kritis Pemikiran Hassan Hanafi (Yogyakarta: LKiS, 1993), hlm. 6-7.

11 Ibid. 
Bagan 1:

Pergulatan Mewujudkan Islam Politik

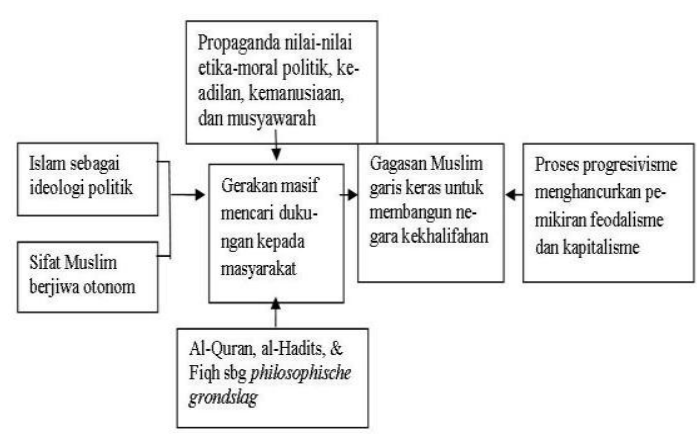

Sejatinya pemikiran-pemikiran Islam fundamentalisme/radikal tidak ada pada ajaran agama Islam. Apabila terminologi politik diletakkan pada perspektif jihad fi sabilillah. Terminologi itu pernah muncul ketika Muslim ditindas oleh kolonialisme Belanda. Dewasa ini terminologi Islam radikal menjadi tidak proporsional ketika bangsa Indonesia merdeka. Pada sisi lain, praktik politik Nabi Muhammad menggunakan konsep 'madani' ketika membangun sistem politik di Madinah. Konsep madani adalah melindungi minoritas etnisitas dan religiusitas dari tindakan represif mayoritas. Karena itu rasionalitas Islam radikal bukan dogma Rasulullah, tetapi hanya ada pada tataran sosial, politik, ekonomi, dan sejarah.

Hal ini bisa dimaklumi bahwa pemikiran Islam radikal merupakan sintesis dari kehendak untuk menghacurkan sisasisa nilai kolonialisme-imperalisme yang masih melekat dalam kehidupan sosial politik, sosial ekonomi, dan sosial budaya, khususnya praktik kolonial dalam implementasi kebijakan politik dan ekonomi. Kuatnya pemikiran Islam radikal dalam konstelasi politik di Indonesia akibat: (1) keberhasilan revolusi Islam di Iran pada 1979, (2) kekuatan ekonomi kapitalisme Barat yang semakin merangsek dan memarjinalkan ekonomi masyarakat
Muslim, dan (3) pemikiran sebagian besar Muslim berpaham radikal bahwa agama landasan teologi pembebasan, sehingga alQuran, al-Hadits, dan Fiqh sebagai philosophische grondslag, dasar negara bangsa Indonesia. ${ }^{12}$

Tidak mengherankan ketika Soeharto jatuh, muncul orde reformasi yang diikuti dengan berdirinya 20 partai Islam, dengan masing-masing basis massanya. ${ }^{13} \mathrm{Di}$ antara 20 partai Islam itu adalah: PKU (Partai Kebangkitan Umat), PNU (Partai Nahdatul Umat), SUNNI, PKB (Partai Kebangkitan Bangsa), PAN (Parai Amanat Nasional), PBR (Partai Bintang Reformasi), PBB (Partai Bulan Bintang), PK (Partai Keadilan), PSII (Partai Syarikat Islam Indonesia), PUI (Partai Umat Islam), PMB (Partai Masyumi Baru), dan lain-lain. Ada dua hal yang dapat disimak mengapa partai-partai Islam muncul pada awal orde reformasi:

1) Pada awal pemerintahan orde baru, Jenderal Soeharto sadar terdapat dua resistensi politik yang bakal dihadapi, yaitu komunisme dan Islam. Untuk menghadapi komunis Soeharto bersinergi dengan kelompok Islam. Pada sisi lain, setelah berhasil membasmi komunis sampai ke akar-akarnya, Soeharto mulai mengawasi umat Islam yang berseberangan dengan kebijakan politiknya. Strategi politik selanjutnya adalah menyederhanakan partai politik menjadi tiga partai, Golkar, PDI, dan PPP. Partai politik di luar mainstream, baik PDI maupun PPP didesain agar tidak dapat menang dalam pemilihan umum. Desain ini mengingatkan strategi politik Belanda yang disebut beamtenstaat untuk domestikasi partai politik, dan menciptakan floating mass (masa mengambang) sehingga akan mendapat keunggulan suara dalam pemilu. Apabila di suatu daerah salah satu partai politik (PDI dan PPP) itu menang, maka pembangunan di daerah itu bakal dihambat.

Jatuhnya orde baru, kemudian

\footnotetext{
12 Ibid.

13 Syarifuddin Jurdi, Pemikiran Politik Islam Indonesia: Pertautan Negara, Khilafah, Masya-rakat Madani, dan Demokrasi (Yogyakarta: Pustaka Pelajar, 2008), hlm. 181-190.
} 
menjadi triggered Muslim untuk mendirikan partai politik Islam. Berdirinya partai politik Islam yang berjumlah 20 partai politik itu, pada satu sisi, wujud dari euphoria demokrasi, tetapi pada sisi lain, partai politik Islam akan sulit sekali mendapatkan electoral threshold 2,5\%.14 Akibatnya banyak partai Islam yang layu sebelum berkembang. Dengan sistem multipartai, serta banyaknya partai politik Islam justru dapat menghambat konsolidasi. Bahkan hingar-bingar pemikiran Islam politik yang akan mendirikan sistem pemerintahan model kekhalifahan dan basis syariat Islam, justru semakin berkurang basis massa mereka, kecuali basis massa militan. Realitas politik tersebut menunjukkan bahwa Islam politik sulit berkembang, dan realitas politik itu merupakan konsekuaensi dari proses Islamisasi pada abad ke-14 yang lalu.

\section{Lima belas Tahun Reformasi Bagi Partai Islam}

Problem utama pasca reformasi dewasa ini, meminjam pendapat Nurcholish Madjid bahwa reformasi belum menghasilkan peradaban civil society yang menjadi landasan demokrasi. ${ }^{15}$ Masyarakat berperadaban baru tidak bakal terwujud apabila hukum tidak ditegakkan secara adil. Rasa keadilan itu harus dimulai dari ketulusan komitmen pribadi. Karena itu peradaban baru membutuhkan pribadipribadi yang tulus yang mengikatkan jiwanya kepada wawasan keadilan. Untuk menggapai ketulusan keadilan para elit politik harus memiliki visi jauh ke depan, dan tidak menjadikan diri mereka sebagai tawanan dalam situasi ruang dan waktu. Elit politik adalah public figure yang sudah seharusnya memiliki pijakan etika dan moral politik, bahkan dalam diri mereka tersembul jiwa dan semangat keterbukaan. Ketiga aspek secara imperatif harus dimiliki oleh public figure. Ketiga aspek itu akan bermutasi menjadi mata air keteladanan bagi seluruh komponen masyarakat, dan pada akhirnya ketiga aspek itu menjadi landasan untuk membangun peradaban baru, yakni demokrasi atau civil society.

Dengan demikian demokrasi atau civil society tidak mungkin terwujud apabila kaum elit politik tidak memiliki ketulusan dalam membangun kehidupan yang lebih adil, dengan berpijak pada etika dan moral politik, serta keterbukaan terhadap kebijakan publik yang ditempuh. Dalam perspektif ini Mochtar Pabottingi menyebut empat modal yang harus dimiliki oleh seorang pemimpin atau elit politik dalam kepemimpinannya atau kenegarawannya, yakni: (1) memiliki sifat terpuji, (2) berperilaku bajik, (3) sikap bertanggung jawab terhadap kebijakan yang sudah ditempuh, dan (4) ketercerahkan pemikiran kaum elit politik berdasarkan pada tujuan hidup luhur atau visi ke depan demi kemaslahatan masyarakat bangsa maupun negara. ${ }^{17}$

Keempat faktor itu menjadi posisi sentral, bahkan sangat imperatif, bahkan posisi empat faktor di atas memacu terwujudnya demokrasi atau civil society.18 Tiadanya empat aspek itu dalam kehidupan politik masa reformasi justru memacu bangkrutnya kepemimpinan partai politik. Ada dua segi memacu kebangkrutan kepemimpinan elit politik dewasa ini:

(2) Kebangkrutan personal akibat tindakan politik yang dilakukan terindikasi tidak terpuji, misalnya tindakan koruptif secara pribadi maupun berjamaah, menghamburkan dana APBN untuk mendapat pembagian prosentase dari dana

\footnotetext{
14 Ibid., hlm. 186.

15 Nurcholish Madjid, Cita-Cita Politik Islam Era Reformasi (Jakarta: Paramadina, 1999), hlm. 163168.

17 Mochtar Pabottingi, "Kepemimpinan dan Demokrasi Kita: Akar-akar Kebangkrutan Kepemimpinan di Era Reformasi, dan Jalan Menuju Kebangkitan”, Prisma, No. 4, Vol. 32 (Jakarta: LP3ES, 2013), hlm. 3-27.

$18 \mathrm{lbid}$.
} 
(1) pembangunan, serta kegiatan studi banding yang diselewengkan menjadi kegiatan jalan-jalan. Seharusnya kegiatan studi banding harus menghasilkan outcomes untuk perbaikan dan pengembangan kelembagaan. Namun, hasil yang diperoleh sekadar melancong ke luar negeri.

Kebangkrutan dalam partai politik yang menyebabkan partai itu ditinggalkan oleh basis massa mereka. Banyak faktor penyebab, di antaranya adalah: (a) Ketegangan di dalam partai politik, yang menyebabkan anggota partai menyeberang ke partai politik lain. Fenomena ini memacu perpindahan basis massa ke partai politik lain. (b) Rendahnya etika dan moral elit partai politik. Banyak di antara anggota partai politik melakukan tindakan yang tidak terpuji, misalnya mem-bully lawan politik, tindak kekerasan, mendeskreditkan agama lain, perzinahan-perselingkuhan, dan lain-lain.

Empat kali pemilihan umum, memilih anggota legislatif maupun presiden dan wakil presiden, sudah diselenggarakan pasca reformasi, yakni pada tahun 1999, 2004, 2009, dan 2014. Dalam empat kali pemilu itu, partai politik Islam mengalami pasang surut, dan angka perolehan partai politik Islam dalam pemilihan umum relatif kecil, yakni di bawah 10\%. Sementara itu mayoritas pemilih beragama Islam adalah $88 \%$ dari populasi penduduk Indonesia yang berjumlah 240 juta jiwa. Fenomena ini bermakna bahwa suara partai politik Islam tidak mencerminkan kekuatan pemilih mayoritas. ${ }^{16}$ Problem utama adalah tidak mencerminkan kekuatan pemilih mayoritas adalah elit politik sangat lemah dalam mengelola civic culture (tradisi budaya politik demokrasi) dan political engagement (perasaan dan ketertarikan pemilih terhadap partai politik Islam) terhadap basis massa partai politik Islam. Rendahnya tingkat kelola dari elit politik terhadap dua aspek di atas berdampak pada rendahnya political interest massa pemilih partai politik Islam. ${ }^{19}$

Faktor psikologis sangat dominan terhadap partisipasi pemilih. Civic culture dan political engagement yang melekat pada partai politik dapat memicu rasa tertarik terhadap partai politik. Pemilih selanjutnya akan mendiskusikan perihal partai itu, termasuk diskusi politik 'siapa saja elit politik' yang dicalonkan menjadi anggota legislatif. Diskusi itu memberi informasi mengenai keyakinan individu terhadap partai politik Islam pilihan. ${ }^{20}$ Seringkali hasil diskusi politik itu justru menimbulkan sisi negatif, yakni individu bermigrasi kepada partai politik non Islam. Problem perpindahan partisipasi politik terhadap partai non Islam, tentu, banyak faktornya. Indikasi perpindahan di samping telah disebutkan di atas, juga karena persoalan sifat toleransi partai politik terhadap agama masyarakat. Isu-isu globalisasi menjadi problem bagi partai politik Islam.

Bagan 2:

Tipologi Partai Politik Islam dan Non Islam

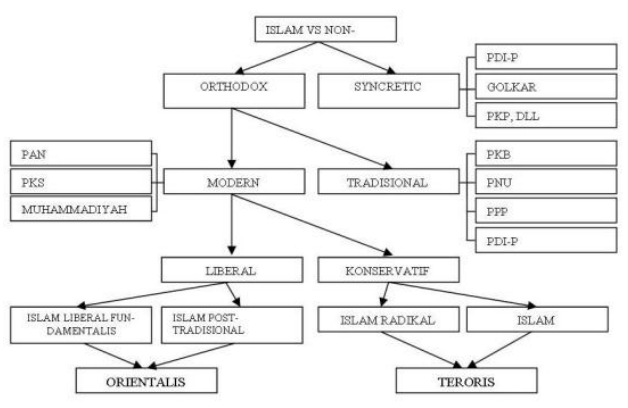

Sumber: Kamaruzzaman BustamanAhmad, Wajah Baru Islam di Indonesia(Yogyakarta: UII Press, 2004), hlm. 177

16 Saiful Mujani,R. William Liddle \& Kuskridho Ambardi, Kuasa Rakyat: Analisis tentang Perilaku Memilih dalam Pemilihan Legislatif dan Presiden Indonesia Pasca-Orde Baru (Jakarta: Mizan Publika, 2012), hlm. 371-467.

$19 \mathrm{lbid}$.

20 lbid. 
Ada tiga isu dalam globalisasi yang berhubungan dengan partai politik Islam, yakni: (1) Isu borderless, dunia tanpa batas, yakni berkembangnya relasi-relasi antarindividu baik dalam konteks lintas batas negara, bangsa, suku, ras, maupun agama. Dengan adanya sifat borderless itu berimplikasi pada tumbuhnya teknologi informasi dan komunikasi. ${ }^{21}$ (2) Tumbuhnya diaspora sebagai akibat borderless itu, sehingga perlu melakukan dekonstruksi untuk memberi pengakuan terhadap identitas budaya masyarakat. Pengakuan identitas menjadi sangat penting, bahkan dalam konteks ini negara maupun partai politik tidak dapat menghegemoni identitas. Penafsiran yang perlu dikemukakan dalam konteks partai politik adalah "stigma politik" negatif maupun positif dapat meningkatkan ataupun menurunkan jumlah perolehan suara dari kelompok basis massa Islam. ${ }^{22}$ (3) Globalisasi memacu timbulnya konflik akibat proses dekonstruksi yang terhambat. Perdebatan mengenai orthodoksi dan sinkretik, modern dan tradisional, liberal dan konservatif, dan radikal dan harmoni merupakan fenomena psikologis yang dapat mempengaruhi perolehan suara pemilih. ${ }^{23}$

\section{Penutup}

Melihat kondisi partai politik Islam pasca reformasi yang begitu lebar dan besar variannya, dan ada kecenderungan elit politik partai politik Islam belum 100 persen menjadikan ideologi Pancasila sebagai philosophische grondslag, tentu, dapat memicu rendahnya partisipasi pemilih. Partai politik Islam yang banyak variannya itu, perlu ditumbuhkan sebuah gagasan untuk menyederhanakan jumlah partai politik Islam. Keberhasilan Soeharto menyederhanakan partai politik menjadi tiga mainstream politik, yakni sosial- demokrat (Golkar), nasionalis (PDI), dan Islam (PPP) merupakan keberhasilan Soeharto yang harus diacungi jempol. Bila tiga mainstream politik itu dihidupkan kembali dalam bentuk baru, dan diletakkan pada fase lima belas tahun reformasi, saya sangat meyakini bahwa partisipasi pemilih terhadap partai politik Islam akan berbanding lurus dengan kekuatan pemilih mayoritas beragama Islam.

\section{Daftar Pustaka}

Croach, Harold. 1986. The Regulation of Military Bureaucratic Regimes: the Indonesian Case. Canberra: ANU Departement of Political and Social Change Research School of Pasific Studies.

Dahl, Robert A. 1992. Demokrasi dan Para

Pengkritiknya. Jakarta: Yayasan

Obor Indonesia.

Bahtiar Effendy. 2001. Masyarakat Agama dan Pluralisme Keagamaan. Yogyakarta: Galang Press.

Kamaruzzaman Bustaman-Ahmad. 2004. Wajah Baru Islam di Indonesia. Yogyakarta: UII Press.

McVey, Ruth. 1982. "The Beamtenstaat in Indonesia", in Benedict Anderson \& Audrey Kahin, Interpreting Indonesian Politics: Thirteen Contributions to the Debate, Interim Reports Series No. 62. Ithaca, New York: Cornell Modern Indonesia Project Cornell University.

Mochtar Pabottingi, "Kepemimpinan dan Demokrasi Kita: Akar-akar Kebangkrutan Kepemimpinan di Era Reformasi, dan Jalan Menuju Kebangkitan", Prisma, No. 4, Vol. 32 (Jakarta: LP3ES, 2013.

21 Kamaruzzaman Bustaman-Ahmad, Wajah Baru Islam di Indonesia (Yogyakarta: UII Press, 2004), hlm. 178-179.

${ }_{22}$ Ibid.; lebih lanjut lihat pula Suárez-Orozco, Marcelo M \& Desirée Baolian Qin-Hilliard. (2004).

Globalization Culture and Education in the New Millenium (Los Angeles: University of California, 2004), hlm. 1.

${ }^{23}$ Kamaruzzaman Bustaman-Ahmad, Wajah Baru Islam di Indonesia, hlm. 179. 
Nurcholish Madjid. 1999. Cita-Cita Politik Islam Era Reformasi. Jakarta: Paramadina.

Saiful Mujani, R. William Liddle \& Kuskridho Ambardi. 2012. Kuasa Rakyat: Analisis tentang Perilaku Memilih dalam Pemilihan Legislatif dan Presiden Indonesia Pasca-Orde Baru (Jakarta: Mizan Publika.

Shimogaki, Kazuo. 1993. Kiri Islam: Antara Modernisme dan Post Modernisme, Telaah Kritis Pemikiran Hassan Hanafi. Yogyakarta: LKiS

Susanto Zuhdi. 2014. Nasionalisme, Laut dan Sejarah. Jakarta: Komunitas Bambu

Syarifuddin Jurdi. 2008. Pemikiran Politik Islam Indonesia: Pertautan Negara, Khilafah, Masya-rakat Madani, dan Demokrasi.Yogyakarta: Pustaka Pelajar 